\title{
The Impact of Voter Equality on the Representational Structures of Local Government
}

In the decade since its first reapportionment decision in Baker $v$. Carr, ${ }^{1}$ the Supreme Court has several times confronted the task of determining the extent to which the requirement of voter equality, or "one man, one vote," is applicable to local government. ${ }^{2}$ The issue has proved a difficult one. While the Court has firmly established that all states must meet rigorous standards of voter equality, ${ }^{3}$ it has acknowledged that a more flexible approach is appropriate in dealing with local governments. ${ }^{4}$ Despite this acknowledgment, there has in fact been a tendency to apply the same strict standards applicable to the states. Given this tendency, the majority of commentators now believe that the voter equality requirement is a significant obstacle to the effective functioning of many existing forms of local government $t^{5}$ and the creation of regional governments. ${ }^{6}$

The voter equality requirement is a serious problem for many of the eighty thousand units of local government that now exist. ${ }^{7}$ Outwardly, most units appear to be identical. They are formed by refer-

1369 U.S. 186 (1962).

2 There are four local government cases dealing directly with voter equality. Abate v. Mundt, 403 U.S. 183 (1971); Hadley v. Junior College Dist., 397 U.S. 50 (1970); Avery v. Midland County, 390 U.S. 474 (1968); Sailors v. Kent County Bd. of Educ., 387 U.S. 105 (1967).

3 Reynolds v. Sims, 377 U.S, 533 (1964), discussed at notes 19-23 infra.

$\&$ Abate v. Mundt, 403 U.S. 183 (1971); Sailors v. Kent County Bd. of Educ., 387 U.S. 105 (1967).

5 See Weinstein, The Effect of the Federal Reapportionment Decisions on Counties and Other Forms of Municipal Government, 65 Colum. L. REv. 21 (1965); Symposium-One Man-One Vote and Local Government, 36 GEO. WASH. L. REv. 689 (1968); SymposiumRestructuring Metropolitan Area Government, 58 GEO. L.J. 663 (1970).

6 Dixon, Rebuilding the Urban Political System: Some Heresies Concerning Citizen Participation, Community, Metros, and One Man-One Vote, 58 GEo. L.J. 955 (1970); Note, Reapportionment on the Sub-State Level of Government: Equal Representation or Equal Vote?, 50 B.U.L. REv. 231 (1970); Note, The Gonstitutionality of the Use of a One UnitOne Vote Rule by Maturing Councils of Government, 1971 UTAH L. REv. 94. But see Note, Reapportionment-Nine Years into the "Revolution" and Still Struggling, $70 \mathrm{MrcH}$. L. REv. 586 (1972).

7 Counties account for 3,043 of these units, municipalities 17,996, townships 17,144, special districts 18,332, and school districts 25,000. Comm. on Economic Development, MODERNIZING LOCAL GOVERNMENT 67 (1966). 
endum votes under state enabling acts, select members of their governing boards by popular vote, and exercise such public powers as eminent domain or taxation. 8 They differ significantly in substantive aspects, however; some local bodies can hardly be thought of as governments. ${ }^{9}$ A special district, for example, that supplies water at cost to all residents of a jurisdiction who do not have wells has a de minimis impact on nonconsumers. The voter equality requirement may hinder the establishment of such districts where the legislature considers it unfair or politically unwise to give every resident voter the same voice as the intended beneficiaries of the special service. In this context, the requirement may limit the kinds of governmental functions that can reasonably be exercised by a local body. It seems undesirable to apply the principles of reapportionment in a manner that would destroy these important mechanisms for linking governmental services to the needs of a local and limited community.

In addition to its impact on many existing forms of local government, the voter equality requirement is seen as a major barrier to the creation of regional governments and other multiple-jurisdiction bodies because it disadvantages the more sparsely populated jurisdictions. These units are likely to be reluctant to subject themselves to regional government if it appears that because of the requirement one or two large jurisdictions would have an absolute majority of the regional representation. ${ }^{10}$ Even if no such majority were created, smaller jurisdictions would be deterred from entering otherwise desirable regional arrangements since allotting regional representation in proportion to population might dilute their control over local affairs to a degree that they would find unacceptable. This consequence of one man, one vote is recognized by state legislatures, which could in some instances impose regional governments if they chose to do so, ${ }^{11}$ but have balked at the idea because of voter resistance in the smaller jurisdictions. ${ }^{12}$ In the absence of the voter

8 S. Sato \& A. VAN ALstyne, STATE ANd Local Government 37-112 (1970).

9 The term "local government" defies definition except as a general label for the following kinds of local bodies: municipalities, counties, New England towns, townships, independent school districts, special districts, and authorities. $I d$. at 5-13.

10 Dixon, supra note 6 , at $981-82$. If a voluntary regional agreement is contemplated, a referendum is the usual method for obtaining voter consent. In addition, the state legislature may be required to enact statutory authorization for local jurisdictions to enter regional arrangements. Lineberry, Reforming Metropolitan Governance: Requiem or Reality, 58 GEo. L.J. 675, 707-08 (1970).

11 In most states, however, there are statutory or constitutional limitations on legislative control of political subdivisions in the form of "home rule" provisions. The extent of these limitations varies widely from state to state. See S. SATo \& A. VAN ALsTYNE, supra note 8 , at 218 et seq.

12 Legislatures seem to be reacting to the feeling that it would be unfair to dilute voter 
equality requirement, there would be room for a compromise system guaranteeing smaller units a minimum amount of representation above that which they would receive on a population basis.

This comment examines the underlying rationale for applying voter equality to local government and analyzes the approach that the Supreme Court has taken toward local reapportionment. Specifically, this analysis probes the implication of the Court's decisions on local reapportionment for several types of local government, including existing limited-function bodies and emerging regional governments.

\section{Reapportionment Principles}

The issue of local reapportionment followed inevitably from the "reapportionment revolution" at the state level13 - a "political thicket"14 that the Supreme Court entered in 1962. In Baker v. Carr, ${ }^{15}$ the plaintiffs alleged that Tennessee's grossly malapportioned state legislative districts denied them equal protection of the laws. ${ }^{16}$ The district court dismissed the complaint on the ground that the claim was nonjusticiable. ${ }^{17}$ The Supreme Court reversed and remanded the case for trial. The Court did not comment on the merits of the allegations, nor did it suggest the form relief might take if the plaintiffs prevailed, except to make the observation that "[i]udicial standards under the Equal Protection Clause are well developed and familiar ...."18

preferences in smaller towns or counties by combining them legislatively with more populous units and that it would be politically dangerous for the legislators from those constituencies as well. Lineberry, supra note 10, at 690-91.

13 Reapportionment decisions at the state level naturally stimulated challenges to local malapportionment and frequently served as models for the analysis of local government cases. In Avery v. Midland County, 390 U.S. 474 (1968), the Supreme Court, in reaching the decision to apply voter equality to local governments, saw "little difference, in terms of the application of the Equal Protection Clause and of the principles of Reynolds $v$. Sims, between the exercise of state power through legislatures and its exercise by elected Iocal officials in the cities, towns, and counties." Id. at 481 .

14 Justice Frankfurter, writing for the Court in Colegrove v. Green, 328 U.S. 549 (1946), first referred to the reapportionment issue as a "political thicket" that the courts ought not enter.

16369 U.S. 186 (1962).

10 The plaintiffs explicitly disavowed an equal protection claim based directly on the theory that the fourteenth amendment entitled them to equal representation and opted for one based on the failure to apply the existing Tennessee constitutional provision for reapportionment. See Neal, Baker v. Carr: Politics in Search of Law, 1962 SUP. Cr. REv. 252.

17 The district court ruled that it lacked jurisdiction over the subject matter and that the complaint failed to state a claim upon which relief could be granted. 179 F. Supp. 824 (M.D. Tenn. 1959).

18369 U.S. at 226. The Court appeared to be following the classic definition of equal protection when it suggested that the apportionment would be in violation of the law if it reflected "no policy but simply arbitrary and capricious action." Id. Justice Frankfurter, 
In Reynolds $v$. Sims, ${ }^{19}$ the Court attempted to give content to this assertion in sustaining an attack on severe disparities among Alabama's state legislative districts, holding that "an individual's right to vote for state legislators is unconstitutionally impaired when its weight is in a substantial fashion diluted when compared with votes of citizens living in other parts of the State."20 The Court explicitly stated that absolute equality was not a necessity and that the state was required only to construct legislative districts "as nearly of equal population as is practicable."21 This wording left open the possibility that some future deviations from population equality might be permissible where "based on legitimate considerations incident to effectuation of a rational state policy ...."22 Thus, Reynolds did not completely forbid the use of factors other than population in the districting process. ${ }^{23}$

Further articulation of the voter equality rule was delayed until 1969, when in Kirkpatrick v. Preisler24 the Court was called on to

dissenting, fixed on the central practical dilemma created by the majority's refusal to meet the question of relief head-on:

[T] he Court naturally shrinks from asserting that in districting at least substantial equality is a constitutional requirement enforceable by courts. Room continues to be allowed for weighting. This of course implies that geography, economics, urban-rural conflict, and all the other non-legal factors which have throughout our history entered into political districting are to some extent not to be fruled out ... . . To some extent -aye, there's the rub.

$I d$. at 269. In his view, the Court was embarking on a venture for which traditional notions of equal protection would be of little guidance.

19377 U.S. 533 (1964). The district court in Reynolds temporarily reapportioned Alabama's house and senate districts for an upcoming primary. The state had last been redistricted in 1901, and in the intervening sixty years, large population shifts had created substantial disparities of population between districts. The district court managed to reduce these variances substantially so that the largest senate district was only half as underrepresented as it had been, while the largest house district was reduced to only five times the size of the smallest house district. Sims v. Frink, 208 F. Supp. 431 (M.D. Ala. 1962).

20377 U.S. at 568. In evaluating the plaintiff's alleged denial of equal protection, the Court discarded the traditional equal protection standard for measuring the validity of state legislative classifications. See Developments in the Law-Equal Protection, 82 HARv. L. REv. 1065 (1969). It treated the plaintiff's allegations as a "right to vote" case bringing it within the ambit of the new or substantive equal protection. The effect of this change is to place the burden for justifying legislative classifications on the state. This pattern is well established for cases dealing with "fundamental rights," Skinner v. Oklahoma, 316 U.S. 535 (1942), one of which is voting, cf. Harper v. Virginia Bd. of Elections, 383 U.S. 663 (1966), or with legislative classifications that are found to be "invidious," cf. Korematsu v. United States, 323 U.S. 214 (1944).

21377 U.S. at 577. The Court first enunciated the "nearly as is practicable" standard for reapportionment in Wesberry v. Sanders, 376 U.S. 1, 7-8 (1964).

22377 U.S. at 579. This is not a reversion to the traditional equal protection standard because the burden of proof remains on the state.

23 At one point, the Court suggested that following political subdivision boundaries in redistricting might be a valid excuse for deviating from population equality. Id. at 578 .

24394 U.S. 526 (1969); Wells v. Rockefeller, 394 U.S. 542 (1969), is a companion case. 
elucidate the meaning of the "as nearly as practicable" standard of voter equality. ${ }^{25}$ In Kirkpatrick, the plaintiffs attacked Missouri's congressional redistricting, which, despite an effort to eliminate many disparities between districts, still contained a three percent difference between the largest and the average-populated districts. ${ }^{26} \mathrm{Missouri}$ argued that this discrepancy was sufficiently small to satisfy the nearlyas-practicable standard and, alternatively, that the variances were justifiable. The Court rejected both arguments and held that the legislature was required to "make a good-faith effort to achieve precise mathematical equality. Unless population variances among Congressional districts are shown to have resulted despite such effort, the State must justify each variance, no matter how small."27 Missouri, however, was unable to show that its legislature had endeavored to achieve absolute equality. ${ }^{28}$ The Court also rejected the state's argument that the population disparities were justified by a rational state policy of protecting the legislative process of political compromise or by special considerations of geography, political history, or regional economics. ${ }^{29}$ It indicated that the only acceptable justifications were those resulting from methodological or mechanical shortcomings in the techniques of redistricting. ${ }^{30}$ The standard formulated in Kirkpatrick is thus significantly more rigid than the substantial equality rule articulated in Reynolds. It approaches a per se rule under which population inequality creates an almost conclusive presumption of invalidity.

\section{LOGAI GOVERNMENT REAPPORTIONMENT DEGISIONS}

The application of the voter equality principle to local government has proceeded along two lines: first, a gradual increase in the scope of the principle, bringing more forms of local government under its re-

25394 U.S. at 528.

$28 I d$. at $528-29$.

$27 \mathrm{Id}$. at $530-31$.

28 The state legislature followed the advice of one of its members, who announced that a two percent deviation from voter equality was sufficient compliance. Id. at 531 .

29 Except for the suggestion that the legislative process of reaching a political compromise over redistricting should be protected, Missouri's other justifications were similar to those put forward in a number of reapportionment cases; deviations are justifiable, for example, if they prevent fragmentation of distinct economic or social groups, result from adherence to boundaries of political subdivisions, offset large populations of nonvoters such as college students and military men, preserve compactness of districts, or anticipate population changes projected to occur between decennial censuses. Id. at 533-36.

30 Justice White's dissent pointed out that the Court's rejection of virtually all conceivable justifications based on convenience or political considerations left only justifications of a technical nature. Id. at 555. The kinds of technical justifications that the Court seemed inclined to permit could arise, for example, where population figures were not available on a street-by-street basis, causing greater inaccuracies in redrawing district lines. 
quirement; and second, a series of changes in the standard of voter equality.

\section{A. The Scope of the Voter Equality Requirement}

The scope issue is unique to local governments. While one state government is indistinguishable from another for the purposes of the voter equality requirement, ${ }^{31}$ local governments do differ significantly, and these differences may warrant diverse approaches to voter equality. The Supreme Court's initial refusal to apply one man, one vote to all local governments seems to have been a recognition of this possibility. In Sailors v. Kent County Board of Education, ${ }^{32}$ the first local government reapportionment case to be decided on the merits, ${ }^{33}$ the Court reviewed a Michigan school consolidation plan that significantly "under-represented" the plaintiff's local high school district on the consolidated countywide school board. The county board was formed under legislation that permitted high school districts, each governed by an elected board, to confederate for the purposes of improving curriculum planning and the use of facilities. The board's statutory authority included the power to appoint the county school superintendent, prepare an annual budget for consolidated programs, and levy an ad valorem tax. The five members of the county board were chosen yearly by an assembly of delegates consisting of popularly elected members of the local school boards. ${ }^{34}$ Justice Douglas, writing for a unanimous Court, held the voter equality requirement inapplicable on two grounds. First, the Board's representational system was "basically appointive rather than elective" because special delegates rather than the total

31 One of the basic distinctions between the state and local levels of government is that a state government can be presumed to govern in some fashion all residents of its jurisdiction, whereas the mere fact that a voter resides within the boundaries of a local government does not necessarily indicate that it has any relationship to him. The lack of any necessary connection is best illustrated by the fairly common instance in which a voter's residence is within the boundaries of several local governments. While the functions of many of these governments are important to the area as a whole, they are frequently so specialized that many such residents have no greater interest in their activities than residents in other parts of the state. Where these special governments have the power to levy a property tax, they can affect more than those with an interest in their services, but others, such as water or sewage districts, frequently pay their way by charging for their services and have a relationship to only those residents in the market for their services. At the state level, empirical questions of this sort do not arise since the state has control over the expansive police power.

32387 U.S. 105 (1967).

33 The Court dismissed two early local government cases on jurisdictional grounds, Moody v. Flowers, 387 U.S. 97 (1967), consolidated with Board of Supervisors v. Bianchi, 387 U.S. 97 (1967), and found no voter equality issue in a third, Dusch v. Davis, 387 U.S. 112 (1967).

34387 U.S. at 109 n.6. 
electorate selected the county board. Second, the board's authority and functions were merely attributes of an administrative, as opposed to a legislative, body. ${ }^{35}$ The Court expressed the view that the Constitution was no impediment to the "need [for] many innovations, numerous combinations of old and new devices, and great flexibility in municipal arrangements to meet changing urban conditions." 36

The two grounds relied on in Sailors illustrate the dimensions of the scope problem in the application of the voter equality requirement to local governments. While they produced the same result in Sailors, they are not parallel considerations, but rather represent different axes along which the Court has found it necessary to travel. The first axis, the elective-appointive distinction, appears to stand for the proposition that one man, one vote applies only to certain procedures for selecting officers-procedures having direct voter involvement. ${ }^{37}$ The second axis, the legislative-administrative distinction, points toward a classification of local governments, for one man, one vote purposes, based on their powers and other substantive attributes. ${ }^{38}$ The latter distinction is considered here first.

1. The Impact of Local Government on Voters-Conflicting Approaches. Since a substantial portion of the more than eighty thousand units of local government operate under statutory powers comparable to or narrower than those in Sailors, ${ }^{39}$ adherence to the administrativelegislative distinction might have exempted many from the voter equality requirement. This possibility was foreclosed, however, in Avery $v$. Midland County, ${ }^{40}$ decided a year after Sailors. In Avery, the plaintiff challenged gross malapportionment in the districts used for selecting commissioners for Midland County, Texas. ${ }^{41}$ The governmental powers exercised by the commissioners were rather insignificant, being limited to maintenance of roads and a few record-keeping functions. ${ }^{42}$ The Court, however, rejected the administrative-legislative distinction urged

35 Id. at 109-11.

36 Id. at 110-1I.

37 See text and notes at notes 71-84 infra.

38 For a critique of the legislative-administrative distinction, see Dixon, Local Representation: Constitutional Mandates and Apportionment Options, 36 Gro. WAsh. L. REv. 693, 735 (1968).

39 See note 7 supra.

40390 U.S. 474 (1968).

41 The smallest district had a population of 476 , while the largest had a population of 67,906. Id. at 475 .

42390 U.S. at 483 . The statutory powers of the commissioners were somewhat broader, but the Texas Supreme Court found that "developments during the years have greatly narrowed the scope of the functions of the Commissioner's [Board] and limited its major responsibilities to nonurban areas of the county." 406 S.W.2d 422, 428 (Tex. 1966). 
by the county board as one of those "neat categories favored by civics texts"43 and adopted a new formula for fixing the scope of application of one man, one vote to local government. The new rule required voter equality where units of local government had "general governmental power" or "power to make a large number of decisions having a broad range of impacts on all citizens ...."44 Apparently, the Court intended by the wording of its test to distinguish between traditional varieties of local government, such as a city or county, and special or limitedfunction local bodies. ${ }^{45}$ The Court rejected the argument that Midland County government was of no importance to the residents of the City of Midland; the county board was held to fall into the "general governmental power" class of local governments and therefore was compelled to redistrict.

The Avery rule was quickly discarded, however, in Hadley $v$. Junior College District. ${ }^{46}$ In that case, voters and residents of the Kansas City School District challenged a Missouri statute that enabled local school districts to federate for the purpose of creating a junior college district. The act provided representation for each constituent school district approximately according to its proportion of the total school-age population in the new district. ${ }^{47}$ If one local district contained between onethird and one-half of the school-age population, it received two of the six trustee-representatives; if between one-half and two-thirds, three trustees; and if over two-thirds, four trustees, with any remaining representation apportioned among the smaller districts. Since the junior college district had only an educational function and a diffuse jurisdiction independent of city or county boundaries, it appeared insignificant enough to be exempt from the voter equality requirement under the Avery test. The Court, however, found two reasons for holding otherwise. First, the Court deemed the Avery test to turn on the impact of a local government on its citizens; but it rejected this approach because it found the question of impact judicially unmanageable due to lack of

43390 U.S. at 482.

44 Id. at $483-85$.

45 The Court noted that "virtually every American lives within what he and his neighbors regard as a unit of local government with general responsibility and power for local affairs. In many cases citizens reside within and are subject to two such governments, a city and a county." $I d$. at 483.

46397 U.S. 50 (1970).

47 The act relied on "school enumeration"-the number of children between the ages of six and twenty residing in the district-as the basis for apportionment, but the Court did not reach the question of the propriety of this method. In the past, the Court has permitted the substitution of voter registration figures for census data where the former is more convenient and fairly approximates population figures. Burns $\mathbf{v}$. Richardson, 384 U.S. 73 (1966). 
standards. ${ }^{48}$ More important, the Court viewed the distinction between general and special governmental powers as artificial; an equal vote, it felt, could be important in any election:" "There is no discernible, valid reason," the Court stated, "why constitutional distinctions should be drawn on the basis of the purpose of the election,"50 adding that "[i]n some instances the election of a local sheriff may be more important than the election of a United States Senator." applying the Avery test, the Court held that the mere fact that a state chooses to select local officials by an elective process creates a conclusive presumption that the local government has a significant impact on all potential voters. ${ }^{52}$

While Hadley rejected any consideration of the purpose of an election, however, it expressed, in apparently contradictory fashion, uncertainty about applying the voter equality requirement to "cases in which the State [chooses to elect] certain functionaries whose duties are ... far removed from normal governmental activities and ... disproportionately effect different groups ...."53 By acknowledging the possibility of an exception for local bodies of this sort, the Court undermined its own assumption that the presence of a popular election was adequate evidence of significant impact on all potential voters. ${ }^{54}$

The Hadley rule applies specifically to cases in which a local government has malapportioned its representational districts. Thus, it clearly forbids "over-representation" of voters in any geographic area. Although it is not done at the state level,, 55 local governments frequently

\footnotetext{
48 But see Kramer v. Free Union School Dist., 395 U.S. 621 (1969); related cases discussed in text and notes at notes $59-63$ infra.

49 It is not clear whether the Court was referring to an equal vote for all voters or only for those who have an interest in the outcome.

60397 U.S. at 54.

$61 \mathrm{Id}$. at 55 .

52 The Court stated that

as a general rule, whenever a state or local government decides to select persons by popular election to perform governmental functions, the Equal Protection Clause of the Fourteenth Amendment requires that each qualified voter must be given an equal opportunity to participate in that election, and when members of an elected body are chosen from separate districts, each district must be established on a basis that will insure, as far as practicable, that equal numbers of voters can vote for proportionally equal numbers of officials.
} Id. at 56 ,

63 Id.

54 Arguably, Fadley does not go as far as the Court's language makes it appear. It would be relatively easy to demonstrate that the junior college district was of importance to most voters simply because of the stake that the community has in education. Certainly, the district was no less significant for the average voter than the Midland County government.

55 States have used racial or economic criteria to restrict the franchise, but invidious classifications of this sort are no longer valid. Harper v. Virginia Bd. of Elections, 383 U.S. 
give preferential representation to special constituencies whose membership is thought to be more directly concerned with the activities of the local government. ${ }^{56}$ Unequal districting would not be an effective means of giving greater representation to these groups since their membership is not identified by place of residence. A local government might, for example, allow property owners alone to elect half of the unit's representatives, while all voters elect the remaining half ${ }^{57}$-a variety of malapportionment relying on personal rather than geographic characteristics of the voting population. ${ }^{58}$ Arguably, any form of preferential representation in elected local governments would be invalid under the Hadley rule since the premise of Hadley is that all voters have a significant stake in local elections. The Court, however, has not applied this premise where preferential representation is not based on unequal districting.

One such method of preferential representation is for the local government to limit the franchise to voters having a direct or indirect interest in its activities. Some support for the view that this form of "over-representation" may not always be invalid can be found in

663 (1966). States can, however, set minimum qualifications for voters related to their competence. Oregon v. Mitchell, 400 U.S. 112 (1970).

56 Cf. Cipriano v. City of Houma, 395 U.S. 701 (1969); Phoenix v. Kolodziejski, 399 U.S. 204 (1970), both discussed in note 63 infra.

57 The formation of a special district often requires an affrmative vote of the majority of property owners. S. SATO \& A. VAN ALSTYNE, supra note 8, at 59-73.

58 In Cooper v. Leslie Salt Co., 70 Cal. 2d 627, 451 P.2d 406, 75 Cal. Rptr. 766 (1969), cert. denied, 396 U.S. 821 (1970), residents of a municipal improvements district attacked the constitutionality of the district's enabling legislation, which gave property owners greater influence in the district's representative selection process. Under this act, residents without real property holdings could vote only for three of the district's five governing board members, while property owners could vote for all five. Moreover, in voting for their two exclusive representatives, property owners were allotted one vote for every dollar of assessed value of their property. The plaintiffs argued that the district violated the voter equality requirement by giving property owners as a group two-thirds more infuence in selecting representation than other residents. They also challenged the district's discrimination between property owners on the basis of the value of their holdings. The California Supreme Court, however, refused to reach the merits of either claim because it found that the legislature was about to remedy the situation.

The plaintiffs' second complaint in Leslie was subsequently considered in Burrey v. Embarcadero Municipal Improvement Dist., 5 Cal. 3d 671, 488 P.2d 395, 97 Cal. Rptr. 203 (1971), involving a local government based on legislation substantially identical to the act in Leslie. In Burrey, the legislation provided that the district's five-man governing board be elected by landowners and that each have one vote for every dollar of assessed valuation of his property. Both individuals and corporations were permitted to vote, and one corporation owned about sixty-five percent of the assessed property in the district. The California Supreme Court invalidated the voting provision of the act on the basis of the voter equality doctrine even though no unequal districting was at issue, remarking: "Instead of 'one person, one vote' we have here a case of 'one corporation, 285,689 votes.' " $I d$. at 679, 488 P.2d at 401, 97 Cal. Rptr. at 209. 
Kramer v. Free Union School District. ${ }^{59}$ In that case, the school district limited the franchise to individuals with property interests in the district or children enrolled in the public schools. The Court held that the state could not exclude otherwise qualified voters from limitedpurpose elections unless "the exclusions are necessary to promote a compelling state interest." 60 While the Court found that no compelling state interest was served by the exclusions, ${ }^{61}$ it intimated that under certain circumstances a state or local government might limit the vote in local elections to those "primarily affected." 62 The Court then proceeded to determine whether in fact the exclusion of certain voters was related to a lack of impact on them by the local government. ${ }^{63}$ Although the Court found that there was little relationship, what is important is that it did not assume, as it did in Hadley, that every qualified voter had a significant interest in any elected local government. It is therefore difficult to reconcile the approaches taken in Kramer and Hadley.

Following the Kramer view, a case can be made for the validity of preferential representation where the classification of voters is directly and rationally related to the effects of local government. In Thompson v. Turlock Irrigation District, ${ }^{64}$ town residents challenged the representation system of a special district created primarily to supply water

50395 U.S. 621 (1969).

60 Id. at 627 .

61 Although the state could not meet the burden of proof required under the compelling state interest test, this does not mean that it is insurmountable. $C f$. Abate v. Mundt, 403 U.S. 183 (1971), discussed in text and notes at notes 91-97 infra.

62 Id. at 632. The New York statute was found to be both under- and overinclusive in that many disqualified voters were found to be directly concerned with the district's activities (e.g., a teacher with no children who lived with friends) and that many qualified voters had no interest in the district.

63 Unlike Hadley, Kramer evidenced a willingness on the part of the Court to determine the importance of an election to various groups of voters. Kramer's approach has been followed in subsequent cases. In Cipriano v. City of Houma, 395 U.S. 701 (1969), the Supreme Court in a per curiam opinion struck down a Louisiana statute that allowed only property owners to vote on the issuance of city revenue bonds. The Court felt that non-property owners were not "substantially less interested" in the level of bonding since the bonds were to be repaid from public utility charges, imposing costs on renters as well as property owners. Id. at 704-05. And in Phoenix v. Kolodziejski, 399 U.S. 204 (1970), the Court invalidated an Arizona restriction of the franchise to property owners in referenda concerning the issuance of general obligation bonds by local governments. The Court found that all residents, whether or not they owned property, were affected by the public facilities and projects financed through general obligation bonding. (The directness of the relationships that the Court found between the voter and the local government is questioned in note 68 infra.) In both cases, the Court indicated that it would have been satisfied if the state could have shown a more rational basis for the exclusionary classification of voters.

61 247 Cal. App. 2d 587, 55 Cal. Rptr. 689 (1967). 
to rural areas for agricultural purposes. Under its enabling legislation, the district was required to consider both land area and population in drawing its representational districts. The resulting system created "under-representation" in one of the more densely populated sections of the irrigation district. Greater equality among voters could be attained, but only at the expense of equality in land area, which the legislature obviously felt should be given full consideration. ${ }^{65}$

Although the requirement of equality in land area meant that rural residents were preferentially represented, the result seems defensible because of the focus of the district's activities. The rural water users were the intended and actual beneficiaries of the service provided by the district, while the townspeople were only incidental beneficiaries in that the town was a purchaser of water from the district. ${ }^{66}$ The rural residents carried the great preponderance of the district's costs because a substantial portion of its operating costs was covered by charging customers for water on a per-gallon basis and because the district was empowered to levy a tax on land only to the extent of its value as unimproved property. Since the district's impact was primarily on a well-defined segment of the population, preferential representation of rural interests would seem to accord with the notion that a majority of the governed should be able to elect a majority of the representation. ${ }^{67}$

While the townspeople were tangentially affected by the district's activities, their interest in the local government was of a substantially different variety. At some future point, their community might have to pay higher prices for water if the irrigation district were poorly managed; in addition, the townspeople might have to bear other costs of the district passed along to them through increased prices for agricultural commodities. But these effects result from contractual relationships and could exist even if the town were excluded from the irrigation district. The decision of townspeople, as consumers, to assume additional costs was not determined by the origin of these costs. Thus, the district's impact on them was a result of the workings of the market and not direct governmental intervention. ${ }^{88}$

65 Without the agricultural need for the district's service, there was little purpose in the government and little chance of its formation, which had to be approved by a substantial number of the rural property owners.

66 The water was apparently supplied at cost on the basis of an intergovernmental agreement entered into after the formation of the district.

67 See Reynolds v. Sims, 377 U.S. 533, 565-66 (1964).

68 In Phoenix v. Kolodziejski, 399 U.S. 204 (1970), the Court relied in part on a "passing the costs along" argument to demonstrate that renters are necessarily affected by local property taxes and therefore by local government. This argument would seem to prove 
Whether the Court will permit preferential representation in a case similar to Thompson remains to be seen. ${ }^{69}$ It might do so by activating Hadley's potential exception for local bodies with greatly disproportionate effects on some groups and by relying on Kramer and related cases $^{70}$ in analyzing the differential impacts of local governments. Greater fairness would seem to result from treating preferential representation, resulting from either unequal districting or exclusion of otherwise qualified voters, under one standard. Kramer's approach seems to be the better one. Continued use of the Hadley rule only perpetuates the questionable assumption that an elective representation structure is sufficient to indicate that a government is affecting the entire population. In reality, it is the actual effect of the government, not the form of selecting representatives, that identifies those individuals who are governed by a local government and thus establishes the group for which voter equality is appropriate.

2. Elective Versus Appointive Methods of Representation. As noted above, the second axis of the scope problem results from the Court's holding in Sailors that a local government using "appointive" means of selecting members of its governing body need not comply with the voter equality requirement. ${ }^{71}$ It is clear that voter equality has no application to representatives appointed by an executive officer such as the governor. The reason is that such action does not contain the requisite elements for a voter discrimination complaint based on the equal protection clause. ${ }^{72}$ It is difficult, however, to specify just what the minimum elements for a voter equality claim are. In Sailors, the countywide school board was chosen by delegates who were themselves popularly elected representatives to their school boards. ${ }^{73}$ Even though this method was a form of indirect election somewhat analogous to the electoral college system, the Court held that the positions were not elective. The line between election and appointment is thus far from obvious. ${ }^{74}$ Although this uncertainty may seem trivial, the dis-

too much, however, since any consumer of goods or services produced in the district could avail himself of the same reasoning whether or not he lived in the district. The market determines who will ultimately bear the costs; from the consumer's point of view, they can hardly be said to be effects of local government.

69 The Wyoming Supreme Court applied somewhat novel reasoning in Associated Enterprises, Inc. v. Toltec Watershed Improvement Dist., 490 P.2d 1069 (Wyo. 1971), calling a local government a public corporation in order to avoid the Hadley rule.

70 See note 63 supra.

71 See text and notes at notes 32-36 supra.

72 See text and notes at notes 78-80 infra.

73 See note 34 supra.

74 Hadley's use of a "popular election" to indicate that the local government is of suf- 
tinction is likely to become one of the most important problems of local reapportionment. ${ }^{75}$

The use of appointed representation by regional governments is one development that will surely bring this issue into prominence. One example of such a system was at issue in People ex rel. Younger $v$. County of El Dorado, ${ }^{76}$ in which the California Supreme Court dealt with an apportionment challenge to a regional governing body. The case involved the constitutionality of a compact between California and Nevada setting up a regional agency to control land development within the Lake Tahoe Basin. ${ }^{77}$ Under the compact, the Tahoe Regional Planning Agency was to have broad powers to enact and enforce a system of land use ordinances for the conservation of the lake's natural environment. Five counties and one city were to be represented on the governing board, and each governor was to appoint one representative at large. The compact delegated the final selection of the six local government representatives to the governing bodies of the jurisdiction they were to represent. Each state set some limitations on which individuals the local units could appoint. The California provisions, which were at issue, required the appointees to be residents of the region and members of the local body that selected them.

The court, relying on the parallel between the El Dorado method of selection and the one used in Sailors, reached the conclusion that the representatives were appointed and that, consequently, "the fact that they do not 'represent' equal numbers of people does not deny those who are 'under-represented' equal protection of the laws."78 In both El Dorado and Sailors, an independent selection procedure in-

ficient importance to all voters to require voter equality will meet the same definitional problems as Sailors' elective-appointive distinction.

75 Bergerman v. Lindsay, 25 N.Y.2d 405, 255 N.E.2d 142, 306 N.Y.S.2d 898 (1969), cert. denied, 398 U.S. 955 (1970), involved a challenge of a New York City charter provision making elected borough presidents ex officio voting members of the board of estimate. The plaintiffs argued that in giving each borough president an equal vote, the charter underrepresented voters in larger boroughs. While the New York Court of Appeals upheld the charter provision, it did so, prior to the Supreme Court's decision in Hadley, on the ground that the board of estimates did not have general governmental powers over the jurisdiction. After Hadley, the result in a similar case would turn on whether there was a popular election bringing it within Hadley's scope rule and an election rather than an appointment bringing it within the Sailors requirement. Although the Hadley and Sailors tests are based on different considerations, the fact that they both turn on similar findings makes the definition of an elective system of selecting representatives of great practical importance.

765 Cal. 3d 480, 487 P.2d 1193, 96 Cal. Rptr. 553 (1971).

77 As required by the compact clause, Congress had approved the bistate agreement. For a full discussion of the purpose of the compact, see Ayer, Water Quality Control at Lake Tahoe: Dissertation on Grasshopper Soup, 1 Ecology L.Q. 3, $50-57$ (1971).

785 Cal. 3d at 505, 487 P.2d at 1209-10, 96 Cal. Rptr. at 569. 
tervened between the voter and the representative finally selected by his jurisdiction. Even if the choice of the voters were made known, it would not be binding on the selection process; any discrimination against voters can thus be only indirect. ${ }^{79}$ In addition, no explicit legislative classification of voters can be clearly identified as depriving them of equal protection since the law on its face does not refer to the general electorate at all. ${ }^{80}$

El Dorado demonstrates that a regional government or other local body ${ }^{81}$ may be able to avoid the voter equality requirement by following the Sailors formula. Although escaping one man, one vote was not the California Legislature's primary motive for setting up the Tahoe agency the way it did, ${ }^{82}$ the Sailors exception might be abused. To preclude this, the Court could expand the scope of the voter equality requirement by adopting an analysis denying exemptions where an improper motive for establishing an appointive system of representation is found. ${ }^{83}$ Even if the scope of the requirement is greatly expanded, however, some forms of local representation, such as those relying on executive appointments, will probably remain permanently outside the domain of voter equality. This means that the use of appointive systems for avoidance purposes will depend largely on the

79 This contrasts with the elective selection procedure in Bergerman v. Lindsay, 25 N.Y.2d 405, 255 N.E.2d 142, 306 N.Y.S.2d 898 (1969), cert. denied, 398 U.S. 955 (1970), discussed in note 75 supra, in that the voters' choice for borough president conclusively determined who would represent the borough on the board of estimate.

80 In some instances, an apparently appointive regional system of representation might be found invalid because it created de facto classifications of voters by relying on local election procedures. A regional body consisting of mayors of the cities within the region utilizing the election procedures of the cities, for example, might be said to incorporate each city as a classification of voters by reference to their selection procedures. Cf. Meadowlands Regional Development Agency v. New Jersey, 112 N.J. Super. 89, 270 A.2d 418 (1970). If either a discriminatory classification, actual or de facto, or a binding election is not part of the regional system of representation, it is probably beyond the reach of the voter equality requirement.

81 In Egan v. Wisconsin State Bd. of Vocational, Technical \& Adult Educ., 332 F. Supp. 964 (1971), a three-judge court upheld the representational structure of a special school district engaged in adult and vocational education. Following Sailors, the court held that the system was basically appointive because the board members were selected by other local officials.

82 One of the major reasons for including elected local officials on regional bodies is that they bring with them the necessary expertise in local government problem solving and are useful in getting their local jurisdictions to cooperate with regional policies. The Tahoe agency needed local officials on its governing board because it relied heavily on local government cooperation in enforcing its policies. Ayer, supra note 77.

83 In other voting rights cases, the Court has been willing to go behind a law seemingly innocuous on its face to strike down sophisticated but indirect methods of discriminating against voters. Cf. Lane v. Wilson, 307 U.S. 268 (1939). 
restrictions imposed by states themselves ${ }^{84}$ and on the relative burden of complying with one man, one vote.

\section{B. The Standard of Voter Equality}

In addition to the scope issue, local government cases have faced the problem of finding a standard for measuring whether a local government is in compliance with the voter equality requirement.85 The compliance issue is important because it serves to define the significance of the scope question. Obviously, if compliance means eliminating only those variances between districts in excess of one or two hundred percent, the issue of the forms of government subject to such a standard will be of little importance. There is, however, substantial overlap in the problems raised by both issues. The same rationale for limiting the scope of the voter equality requirement where a local government has a greatly disproportionate impact on certain voters might be applied in similar instances to justify deviation from precise numerical equality among districts. This overlap would seem to require some uniformity in handling the scope and compliance issues.

In Avery, the Court adopted the Reynolds view when it held that the Midland County commissioner districts must be redrawn without substantial inequality. ${ }^{86}$ Hadley, while appearing to retain this approach, in fact imposed more restrictive requirements on local governments. ${ }^{87}$ Conceding that the scheme in Hadley achieved roughly proportional representation, the Court nevertheless found it objectionable since it "systematic[ally] discriminat[ed] against voters ... in more populous ... districts." 88 The ten percent disparity that the plaintiffs attacked arose because the plan allotted only fifty percent of the representation to school districts containing between one-half and two-thirds of the school-age population. ${ }^{89}$ This meant that any district with more than one-half but less than two-thirds of the school-age population would always be somewhat underrepresented. The majority opinion, as Justice Harlan's dissent pointed out ${ }^{90}$ seems to suggest that the plan's vice was not that it marginally underrepresented the plaintiff's district, but that this and other discrepancies were technically avoidable. Al-

84 State constitutions and legislative acts frequently specify that certain forms of local government shall be elective. S. SATo \& A. VAN ALSTYNe, supra note 8, at 393-96.

85 Kirkpatrick v. Preisler, 394 U.S. 526 (1969), deals with this issue at the state level.

86390 U.S. at $485-86$.

87 Justice Harlan's dissent indicates that Hadley applies Kirkpatrick's precise equality standard. 397 U.S. at $66-67$.

$88 \mathrm{Id}$. at 57.

89 See text at note 47 supra.

90 See note 87 supra. 
though the Court in Hadley failed to mentioned Kirkpatrick's requirement of a good faith effort to eliminate all avoidable variances, Hadley clearly moved far in the direction of requiring precise mathematical equality in local reapportionment.

In Abate v. Mundt, ${ }^{91}$ the Court last year disavowed the rigid standard of population equality implicit in Hadley. Abate involved a challenge to the reapportionment of the supervisorial districts of Rockland County, New York under a plan that relied on township lines as districts in a system of multimember constituencies. Under the plan, the least populous town, Stoney Point, was allotted one representative. The number of representatives received by the remaining towns was determined by dividing each of their populations by that of Stoney Point and rounding to the nearest whole number.92 Despite an eight percent deviation from equality in one township, the Court upheld the plan because it found that it contained no "indigenous bias."93 This finding apparently reflected the Court's view that the Rockland County plan, unlike the plan in Hadley, was not systematically biased against any identifiable groups or particular districts. ${ }^{94}$ Rather, only random bias could result from the rounding-off procedure. The Court also found, however, that lack of bias alone did not validate these deviations from voter equality and required the further justification that the plan encouraged effective local government. ${ }^{95}$

91403 U.S. 183 (1971).

92 Id. at 184 . On the constitutionality of multimember districts, see Whitcomb v. Chavis, 403 U.S. 124 (1971), a companion case to Abate, and Fortson v. Dorsey, 379 U.S. 433 (1965).

93403 U.S. at 186. Framing the issue of voter inequality in terms of bias against one group or another is a marked departure from the Baker and Reynolds view that the right to an equal ballot is a personal right enforceable by individual voters.

34. It is difficult, however, to see how the bias in Hadley was any more systematic since the Missouri State Legislature created the apportionment scheme before any of the districts were formed and without reference to their population size. Any bias that existed arose not from the formula but from the relative size of high school districts that joined the junior college district.

95403 U.S. at 185. The Court found justification in the county's desire to continue existing township lines as boundaries for representational districts, observing that local government in the county depended on a network of functional interrelationships between the county and towns that the new apportionment plan attempted to preserve. Under the previous system of county government, township officials were also members of the county board, which helped to create an atmosphere of cooperation between towns and the county. The Court found that the new system tended to encourage the continuance of this pattern of dual office holding because township officials could more easily run for county office in districts that corresponded to their own jurisdictions.

Neither the New York Court of Appeals nor the Supreme Court mentioned the common law rule against dual office holding without express statutory authorization, McDonough v. Roach, 35 N.J. 153, 171 A.2d 307 (1961), or the various statutory codifications and refinements of that doctrine in New York, see Lillich \& Linton, Incompatible Municipal Offices in New York, 28 FordhaM L. REv. 463, 474 (1959). 
Hadley and Abate could perhaps be reconciled by considering the latter to be a special exception in which the local government succeeded in demonstrating that a compelling interest was being served by the deviations from voter equality ${ }^{96}$ It is difficult, however, to characterize Abate in this manner since the justifications offered were of a kind that could be presented by virtually any local government. ${ }^{97}$ The crucial factor in Abate, therefore, appears to be the absence of systematic discrimination. This finding should be sufficient to support the conclusion that greater equality is not necessary. If it appears that a classification of voters, in this case by districting, operates to exclude or noticeably diminish the influence of an identifiable interest group, it would be invalid. If it is merely an imperfect classification that does not single out any interested group for discriminatory treatment, modest inequalities would appear harmless. Following logic similar to that of Kramer ${ }^{98}$ the concern should be whether any affected groups are significantly discriminated against by the deviations, not simply whether numerical discrepancies exist. Viewed in this manner, Abate is a rejection of Hadley's focus on technically avoidable deviations.

On the ground either that there was no significant bias in the Rockland County plan or that its deviations from equality were justifiable, - Abate is an important case for local governments. It gives them a measure of flexibility in complying with the voter equality requirement that may assist them in governmental reorganization. It also provides leeway for population changes that could otherwise quickly invalidate an apportionment scheme. Abate does not directly resolve any of the difficulties in determining the scope of application of one man, one vote to local government. Broadly viewed, however, it lends support to an approach that looks at the actual effect of a local government on potential voters rather than one that infers a significant effect from the merely formal attribute of elective representation. Moreover, by permitting less than exactly equal representation, Abate may provide regional governments with an alternative to the appointive systems sanctioned by Sailors. Within the margin of inequality allowed by Abate, local governments may be able to strike the kind of compromises that make regional government possible. Even if Abate's tolerances are

96 This may be an indication that the burden of proof carried by the state in substantive equal protection cases has lessened somewhat.

97 At bottom, Abate's justifications seem to be a defense of the status quo acceptable because it was shown that the old system was a relatively effective way of conducting local government.

98 See text and notes at notes 59-63 supra. 
too narrow, it is still a hopeful indication that the Court will look more favorably on the practical considerations of maintaining effective local government.

Lock Holmes 